\title{
Patrimoni científic escolar
}

\author{
Anna Plarromaní (rmelia@xtec.cat) \\ Tura Puigvert (mpuigver@xtec.cat) \\ Rosa Maria Melià (rmelia@xtec.cat) \\ ApFQc, Grup Patrimoni científic escolar - Mataró
}

Fem una crida a que es valori el patrimoni que cada centre ha acumulat pel sol fet del temps que ha passat des de la seva inauguració.

\section{CONTEXT}

Dia a dia en cada centre s'està construint una història. El professorat que arriba a un centre passa a formar part d'un departament, d'un claustre de professors i d'una comunitat educativa. Volem animar el professorat dels centres de Catalunya que ja tenen uns anys d'història a documentar-se sobre el llegat dels que els han precedit. Per la nostra formació ens adrecem especialment al professorat de ciències, però és una tasca que es pot estendre a tota la comunitat educativa. A cada departament s'hi poden trobar petits tresors que parlen de la història del centre, de la història de l'ensenyament, de la història de la societat que ens envolta.

Amb el temps, l'aspecte dels materials canvia, alguns objectes es deterioren i s'envelleixen fins a tornar-se atrotinats i pràcticament inservibles, altres cauen en desús i allà, en un racó, van veient com la pols els cau al damunt i ningú els toca, ningú els mira; corren el perill de ser llançats. Si se salven, en algun moment algú es preguntarà: què és això, per què servia? Aleshores comença la recerca històrica i es descobreix el seu valor. Això permet comparar èpoques, maneres de fer, maneres d'entendre, etc. Passen a ser objectes culturals; alguns, de valor incalculable. Qui els va fer? De quins materials està fets? Com funcionaven? Per què servien? Com concebien la ciència les persones que els manejaven?

\section{LA NOSTRA EXPERIÈNCIA}

\section{Quina feina estem fent a Mataró?}

Amb l'autorització dels Serveis territorials de la demarcació del Maresme i Vallès Oriental, amb la col-laboració de les direccions dels Centres i especialment de professorat de ciències i amb la complicitat de persones responsables del Museu de Mataró, des de fa un parell d'anys hem anat inventariant el material antic que encara hi ha en els centres d'ensenyament secundari, públics i privats, de la nostra ciutat, així com alguns de la comarca.

Hem aconseguit inventariar tot el material que hem considerat d'un cert valor: I'hem etiquetat; gràcies al suport de l'Ajuntament de Mataró n'hem fet fotografies de qualitat; hem cercat el seu nom tècnic, la seva funció i les aplicacions didàctiques. Els materials més antics els hem trobat en centres privats d'ordes religiosos i procedeixen principalment d'empreses alemanyes i franceses. Els catàlegs antics que es conserven en alguns centres i que tenen valor per si mateixos, ens han ajudat a fer la classificació. Per altra banda, la informació que es pot trobar a la xarxa telemàtica i que està a l'abast de tothom han sigut un suport fonamental per poder documentar aparells que mai hem fet funcionar en les nostres classes.

\section{Com hem estès el radi d’acció?}

Hem contactat amb la Xarxa d'Escoles Històriques de Barcelona, grup que està fent un treball de cerca de la historia escolar en tots els àmbits del coneixement, així com amb el professorat de I'INS Menéndez Pelayo que han tingut l'encert de convertir l'institut en un dels referents històrics de Barcelona i fer que l'alumnat propi estimi la història del seu centre.

Pel que fa al material científic hem pogut evidenciar que un institut de Barcelona, concretament L'INS Infanta Isabel, conserva pràcticament íntegre l'equip Torres Quevedo amb la seva taula-armari original, la qual servia per muntar les experiències magistrals amb el material del seu interior. La celebració del cinquantenari del centre ha estat una ocasió per potenciar la rehabilitació d'aquest material i posar-lo en valor. 
El fet d'estendre el radi d'acció ens ha permès completar equips, encaixant catàlegs trobats en uns instituts amb els components dels equips que hem trobat en altres. D'aquesta manera, hem pogut reproduir algunes de les pràctiques que es prescriuen en els guions i que tenim previst gravarles en vídeo per deixar documentació virtual de la seva existència.

\section{Altres iniciatives existents}

En altres comunitats autònomes d'Espanya existeixen alguns instituts que han muntat museus amb el material antic i permeten fer-ne una visita virtual. També hi ha societats i associacions de centres històrics que vetllen per la conservació i difusió del seu patrimoni educatiu com ara la Sociedad para el Estudio del Patrimonio Histórico Educativo, l'Asociación Nacional para la defensa de los Institutos históricos (Àmbit: España) o la Red de institutos históricos (Àmbit: Andalucia).

\section{Relació de materials que es poden trobar en centres públics:}

Tipologia dels equips didàctics antics dels laboratoris de ciències dels instituts històrics enviats pel MEC:

- Torres Quevedo

- ENOSA

- SOGERESA

- Làmines, maquetes, col-leccions, models moleculars, aparells òptics, animals dissecats, etc.

\section{Característiques dels materials que es poden trobar en centres privats:}

En el nostre cas tots es troben en institucions religioses. Hem observat que aquests materials són diferents ja que els adquirien a firmes estrangeres, segurament pel fet de pertànyer a institucions d'abast internacional. Les firmes de cases antigues que hem pogut referenciar són:

- Leybold Nachfolder de Colònia

- Kohln de Berlin

- J. Ganzer. Representant a Barcelona Portal de l'Àngel, 19

- E. Ducretet

- Radiguet

- Massiot

- Breguet

- Material escolar científico. Suc. Esteva Marata. Rda. Universitat. Barcelona

\section{LA NOSTRA DEMANDA}

Demanem al professorat que es trobi amb instruments d'alguna d'aquestes marques comercials que acabem d'esmentar o amb altres materials antics que es posi en contacte amb nosaltres, per tal que entre tots els traguem de l'oblit, els donem a conèixer, els atribuïm el valor històric que tenen i els trobem una nova utilitat didàctica. 